\title{
KESESUAIAN PEMANFAATAN RUANG PADA ZONA KHUSUS (PELABUHAN) DI KAWASAN PESISIR TELUK BUNGUS KOTA PADANG
}

\section{SUITABILITY OF THE SPATIAL UTILIZATION ON SPECIAL ZONES (PORT) IN THE COASTAL REGION OF BUNGUS BAY PADANG CITY}

\author{
Aprizon Putra ${ }^{1,2}$, Ahmad Iqbal Baqi ${ }^{1}$, Fuji Astuti Febria ${ }^{1}$, Wilson Novarino ${ }^{1}$, Dedi Hermon ${ }^{2}$, Indang Dewata ${ }^{2}$, Try Al \\ Tanto $^{3}$, Semeidi Husrin ${ }^{4}$, Suparno ${ }^{5}$, Harfiandri Damanhuri ${ }^{5}$ \\ ${ }^{1}$ Program Studi Magister Ilmu Lingkungan - Universitas Andalas, Padang \\ Limau Manis, Pauh, Padang Sumatera Barat 25175 \\ ${ }^{2}$ Program Studi Doktor Ilmu Lingkungan - Universitas Negeri Padang, Padang \\ Jl. Prof. Hamka, Air Tawar, Padang Utara, Padang Sumatera Barat 25171 \\ ${ }^{3}$ Loka Riset Sumber Daya dan Kerentanan Pesisir, BRSDM KP \\ Jl. Raya Padang-Painan Km 16 Padang, Sumatera Barat 25227 \\ ${ }^{4}$ Pusat Riset Kelautan, BRSDM-KP \\ J1. Pasir Putih II Lantai 4, Ancol Timur, Jakarta Utara 14430-DKI Jakarta \\ ${ }^{5}$ Fakultas Perikanan dan Ilmu Kelautan - Universitas Bung Hatta \\ Jl. Sumatera, Ulak Karang, Padang Sumatera Barat 25133 \\ e-mail : indangdewata@fmipa.unp.ac.id
}

Diterima tanggal: 29 November 2018 ; diterima setelah perbaikan: 26 Agustus 2020 ; Disetujui tanggal: 27 Agustus 2020

\begin{abstract}
ABSTRAK
Pemanfaatan ruang yang tidak sesuai dengan perencanaan pada kawasan pesisir Teluk Bungus telah menimbulkan dampak pada terbatasnya ruang yang berfungsi sebagai zona pemanfaatan umum dan zona lindung. Ketidaksesuaian pemanfaatan ruang tersebut disebabkan belum dilakukan identifikasi pemanfaatan ruang secara eksisting. Dimana berpotensi memunculkan konflik antar ruang yang berbeda penggunaan. Analisis pemanfaatan ruang yang belum dilakukan meliputi sejauh mana ruang-ruang tersebut berpotensi mematikan ruang lain dan berpotensi untuk tetap berkembang sebagaimana peruntukannya. Penelitian ini bertujuan untuk mengetahui kesesuaian pemanfaatan ruang pada zona khusus (Pelabuhan) di kawasan pesisir Teluk Bungus, yaitu: 1) PPS (Pelabuhan Perikanan Samudera Bungus); 2) Pelabuhan Pertamina (Persero) Teluk Kabung; dan 3) PLTU Teluk Sirih. Metode yang digunakan adalah pembobotan skoring terhadap parameter lingkungan dengan pendekatan Sistem Informasi Geografi (SIG). Hasil penelitian menunjukkan pada zona khusus pada kawasan pesisir Teluk Bungus, yaitu: 1) PPS Bungus dengan luas 26,15 ha menunjukkan kategori sangat sesuai dengan skor 90; 2) Pelabuhan Pertamina (Persero) (Persero) dengan luas 19,2 ha menunjukkan kategori sangat sesuai dengan skor 90; dan 3) PLTU Teluk Sirih dengan luas 46,32 ha menunjukkan kategori sesuai dengan skor 63.
\end{abstract}

Kata Kunci: Kesesuaian, Zona Khusus, Kawasan Pesisir, Teluk Bungus.

\begin{abstract}
Spatial utilization that is inconsistent with planning in the coastal region of Bungus Bay has had an impact on the limited space that serves as a common utilization zone and a protected zone. Incompatibility of space utilization of such space because no identification of existing spatial utilization on existing. Where potentially bring up conflicts between that different of spatial utilization. Spatial utilization analyzes that have not been done include the extent to which these spatials potentially turn off other spaces and have the potential to remain expanding as intended. This study aims to determine the suitability of the spatial utilization on special zones (port) in the coastal region of Bungus Bay, i.e: 1) Bungus PPS (Ocean Fishing Port); 2) Pertamina (Persero) Port of Teluk Kabung; and 3) Teluk Sirih PLTU. The method used is weighting scores on environmental parameters with Geographic Information System (GIS) approach. The results of this study indicate the special zone on the coastal region of Bungus Bay, i.e: 1) PPS Bungus with an area of 26.15 ha indicates the category is very suitable with score 90; 2) Pertamina (Persero) Port (Persero) with an area of 19,2 ha indicates the category is very suitable with score 90; and 3) Teluk Sirih PLTU with an area of 46,32 ha indicates the category is suitable with score 63.
\end{abstract}

Keyword: Suitability, Special Zones, Coastal Region, Bungus Bay.

Kesesuaian Pemanfaatan Ruang Pada Zona Khusus (Pelabuhan) di Kawasan Pesisir Teluk Bungus Kota Padang - Aprizon Putra, Ahmad Iqbal Baqi, Fuji Astuti Febria, Wilson Novarino, Dedi Hermon, Indang Dewata, Try Al Tanto, 


\section{PENDAHULUAN}

Kawasan Teluk Bungus yang terletak di Selatan Kota Padang memegang peranan penting, tidak hanya bagi Provinsi Sumatera Barat khususnya Kota Padang, tetapi juga Indonesia bagian Barat pulau Sumatera (Tanto et al., 2014; Husrin et al., 2015; Yulius et al., 2014; Fadhilah et al., 2020). Industri perikanan dari Pelabuhan Perikanan Samudera (PPS) Bungus merupakan salah satu andalan pada kawasan ini dengan tangkapan ikan seperti jenis tuna mata besar (Thunnus obesus), tuna madidihang (Thunnus albacares), cakalang (Skipjack tuna), dan tongkol abu-abu (Longtail tuna). PPS Bungus juga merupakan tempat pendaratan kapal dengan bobot 51-100 GT (Dini et al, 2016). Selain itu kawasan Teluk Bungus telah lama menjadi salah satu pusat pariwisata dan pusat distribusi Pertamina di Provinsi Sumatera Barat.

Perkembangan pembangunan di kawasan Teluk Bungus tidak diimbangi dengan konservasi ekosistem pesisir yang ada. Putra et al., (2016) menjelaskan bahwa mangrove sebagai zona lindung sempadan pantai dan sungai mengalami penurunan luasan dari 75,2 ha tahun 2008 menjadi 73,3 ha tahun 2014. Teluk Sirih mengalami penurunan luasan mangrove secara signifikan sejak tahun 2008, dimana dari 4,11 ha tahun 1995 menjadi 2,48 ha tahun 2008 dan tidak terlihat lagi sejak tahun 2008. Punahnya mangrove sebagai zona lindung terjadi akibat konversi lahan yang diperuntukkan bagi Proyek Elektrifikasi Nasional $10.000 \mathrm{mw}$, yakni dengan dibangunnya Pembangkit Listrik Tenaga Uap (PLTU) berkapasitas $2 \times 112 \mathrm{mw}$ di bagian Selatan kawasan Teluk Bungus sejak tahun 2007. Kondisi yang sama terjadi pada mangrove di Muaro Sako Labuhan Tarok, dimana terjadi penurunan luasan secara signifikan dari 20,7 ha tahun 2014 menjadi 10,9 ha tahun 2015. Turunnya luasan mangrove terjadi akibat konversi lahan yang diperuntukkan untuk pembangunan industri Crude Palm Oil (CPO) yang dilengkapi dengan dermaga dan reklamasi perairan pada lahan seluas 79 ha. Lokasi tersebut berdekatan dengan kegiatan pariwisata, pelabuhan, pertanian dan permukiman dengan mengkonversi mangrove dan bekas pabrik kayu PT. Singkiong yang ada sebelumnya di lokasi tersebut.

Berdasarkan Peraturan Menteri Kelautan dan Perikanan (PERMEN KP) No. 23 Tahun 2016 tentang Perencanaan Pengelolaan Wilayah Pesisir dan Pulau-Pulau Kecil, maka suatu kawasan pesisir diharuskan memiliki zona lindung yang merupakan zona perlindungan yang di dalamnya terdapat zona preservasi dan zona penyangga.
Hermon et al., (2018) menambahkan bahwa pertimbangan daya dukung lingkungan tetap merupakan syarat utama seperti sempadan pantai, sempadan sungai, dan zona khusus untuk kawasan cepat berkembang.

Faktor-faktor yang menjadi kendala dalam mewujudkan kawasan pesisir sesuai dengan PERMEN KP No. 23 Tahun 2016 disebabkan regulasi atau kebijakan pada Peraturan Daerah (PERDA) No. 4 Tahun 2012 yang tidak ditindaklanjuti dengan Undang-Undang (UU) No. 27 Tahun 2007 tentang Pengelolaan Wilayah Pesisir dan Pulau-Pulau Kecil (RZWP3K) yang membiarkan pertumbuhan sektor perindustrian pada kawasan yang dialokasikan sebagai zona perikanan dan pariwisata. Faktor penyimpangan tata ruang pada kawasan Teluk Bungus dan faktor perencanaan yang berorientasi ekonomi (economic oriented) telah merubah rona lingkungan kawasan Teluk Bungus sebagai kawasan sentra perikanan dan pariwisata menjadi kawasan industri. Penelitian ini bertujuan untuk mengetahui kesesuaian pemanfaatan ruang pada zona khusus (pelabuhan) di kawasan pesisir Teluk Bungus.

\section{BAHAN DAN METODE}

Penelitian ini dilakukan pada kawasan pesisir Teluk Bungus yang secara administrasi berada di Kecamatan Bungus Teluk Kabung Kota Padang. Secara geografis, kawasan ini terletak pada koordinat $100^{\circ} 22^{\prime} 23^{\prime \prime} B T-$ $100^{\circ} 29^{\prime} 13^{\prime \prime} \mathrm{BT}$ dan $0^{\circ} 59^{\prime} 1{ }^{\prime \prime} L S-1^{\circ} 5^{\prime} 44^{\prime \prime} L S$ dengan panjang garis pantai $\pm 21.050 \mathrm{~m}$ dan panjang teluk $5.418 \mathrm{~m}$.

Lokasi penelitian dibatasi (buffer) dengan jarak $500 \mathrm{~m}$ dari garis pantai ke arah darat dan ke arah laut (Li et al., 2016) seluas 980,19 ha untuk perairan (laut dan sungai) dan seluas 911,13 ha dari garis pantai ke daratan seperti yang terlihat pada Gambar 1. Secara keruangan pesisir Teluk Bungus merupakan wilayah fungsional, meliputi perairan, tepi pantai dan daratan.

Penentuan lokasi penelitian dilakukan dengan pendekatan Sistem Informasi Geografis (SIG) berdasarkan poligon pada data vektor penggunaan lahan. Selanjutnya di overlay dengan data vektor peruntukan kawasan dalam peta 1) RTRW Kota Padang 2010-2030; 2) Rencana Alokasi Ruang PERDA No. 2 Tahun 2018 tentang Rencana Zonasi Wilayah Pesisir dan Pulau-Pulau Kecil (RZWP3K) Provinsi Sumatera Barat; 3) Keputusan Menteri Kelautan dan Perikanan (KEPMEN KP) No. 82 Tahun 2015 tentang Wilayah Kerja dan Wilayah Pengoperasian Pelabuhan 


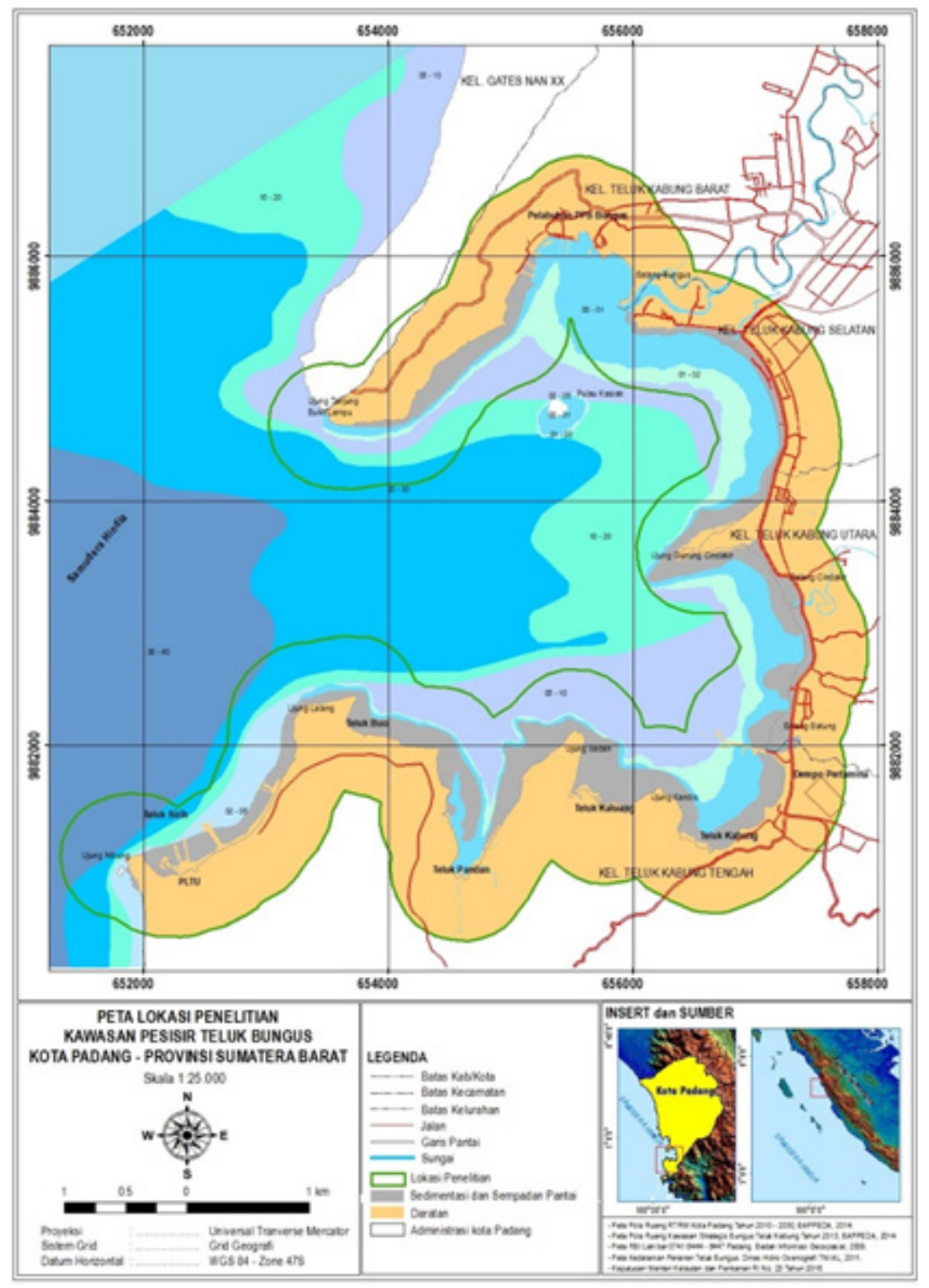

Gambar 1. Peta lokasi penelitian di kawasan pesisir Teluk Bungus.

Figure 1. Map of research location in the coastal region of Bungus Bay.

Perikanan Samudera Bungus sebanyak 3 lokasi untuk zona khusus (Tabel 1) di kawasan pesisir Teluk Bungus.

Setelah lokasi penelitian yang ditentukan, kemudian dilakukan cek lapangan menggunakan Global Position System (GPS). Pengamatan serta pengumpulan data lapangan adalah sebagai data informasi pada analisis kesesuaian parameter (Tabel 2) pada zona khusus pada kawasan pesisir Teluk Bungus, yaitu:

Tabel 1. Lokasi penelitian

Table 1. Research Location

\begin{tabular}{lll}
\hline Nama lokasi & \multicolumn{2}{l}{ UTM-47 S } \\
& X & Y \\
\hline Pelabuhan PPS & 655332 & 9886039 \\
Pelabuhan Pertamina (Persero) & 657372 & 9881754 \\
PLTU Teluk Sirih & 652690 & 9880914 \\
\hline
\end{tabular}

Penentuan konstituen pasang surut dengan menggunakan metode leastsquare sebagai data utama terkait kondisi oseanografi pelabuhan. Dengan nilai konstituen yang dihasilkan tersebut, sehingga penentuan tipe pasang surut yang terjadi menggunakan rumus bilangan Formzahl (F) (Bakosurtanal, 2007), yaitu:

$$
F=\frac{A_{K 1}+A_{O 1}}{A_{M 2}+A_{S 2}}
$$

dimana,

$\mathrm{F} \quad=$ nilai bilangan Formzahl .

AK1, AO1 = amplitudo konstanta pasang surut tunggal utama.

AM2, AS2 = amplitudo konstanta pasang surut ganda utama 
Klasifikasi karakteristik pasang surut berdasarkan nilai bilangan Formzahl tersebut adalah (Bakosurtanal, 2007; Tanto et al, 2016):

$0<\mathrm{F}<0,25$ : semi diurnal, dimana dalam sehari terjadi dua kali pasang dan dua kali surut dengan bentuk gelombang simetris.

$0,25 \leq \mathrm{F}<1,5$ : campuran condong semi diurnal, dalam sehari terjadi dua kali pasang dan dua kali surut. bentuk gelombang pasang pertama tidak sama dengan gelombang pasang kedua (asimetris) dengan bentuk condong semi diurnal.

$1,5 \leq \mathrm{F} \leq 3,0$ : campuran condong diurnal, dalam sehari terjadi dua kali pasang dan dua kali surut. Bentuk gelombang pasang pertama tidak sama dengan gelombang pasang kedua dengan bentuk condong diurnal.

F $>3,0$ : diurnal, dalam sehari terjadi sekali pasang dan sekali surut.

Data tinggi gelombang sebagai data utama terkait kondisi oseanografi pelabuhan diperoleh dari situs European Centre for Medium-Range Weather Forecasts (ECMWF) pada koordinat $1^{\circ} 0{ }^{\prime} 0.00^{\prime \prime}-1{ }^{\circ} 7^{\prime} 30.00$ 'LS dan $100^{\circ} 15^{\prime} 0.00^{\prime \prime}-100^{\circ} 22^{\prime} 30.00$ ”'BT.
Pengukuran kualitas air laut sebagai dilakukan pada musim hujan menggunakan alat portabel (Water Quality Meter-TOA) untuk parameter kimia perairan terdiri dari $\mathrm{pH}$, salinitas serta DO dan suhu untuk parameter fisika perairan, sedangkan kecerahan perairan di ukur menggunakan alat Secchi disk. Pengambilan sampel kualitas air laut untuk uji laboratorium diperoleh dengan cara pengambilan sampel air menggunakan botol Nansen pada kedalaman 1-3 m pada musim hujan, yang terdiri dari parameter kimia seperti nitrat, minyak dan lemak serta BOD. Parameter pencemaran perairan dari logam terlarut seperti kadmium $\mathrm{Cd}$, kromium heksavalen $\mathrm{Cr}+6$, timbal $\mathrm{Pb}$ dan tembaga $\mathrm{Cu}$.

Data dinamika pantai diperoleh dari overlay data shapefile (SHP) dari peta-peta garis pantai kota Padang yang dikeluarkan oleh Badan Informasi Geospasial tahun 2008, dimana selanjutnya data digitasi tersebut dioverlay dengan data citra satelit Landsat OLI tahun 2017, yang bertujuan untuk melihat perubahan garis pantai sebagai data analisis bagaimana dinamika garis pantai dilokasi penelitian dan didukung dengan pengukuran lapangan terhadap kondisi eksisting sebenarnya.

Pendugaan kelayakan lingkungan ini dilakukan dengan

Tabel 2. Parameter kesesuaian zona khusus

Table 2. Parameter of the suitability of special zone

\begin{tabular}{|c|c|c|c|c|}
\hline Parameter & Kriteria & Angka & Bobot & Skor \\
\hline \multirow[t]{2}{*}{ Pasang surut (cm) } & $<100$ & 2 & 2 & 4 \\
\hline & $>100$ & 0 & 0 & 0 \\
\hline \multirow[t]{3}{*}{ Tinggi gelombang (m) } & $<1$ & 2 & 5 & 10 \\
\hline & $1-2$ & 1 & 5 & 5 \\
\hline & $>2$ & 0 & 0 & 0 \\
\hline \multirow[t]{2}{*}{ Dinamika pantai abrasi } & Tidak berada pada zona abrasi & 2 & 4 & 8 \\
\hline & Berada pada zona abrasi & 0 & 0 & 0 \\
\hline \multirow[t]{2}{*}{ Dinamika pantai akresi } & Tidak berada pada zona akresi & 2 & 4 & 8 \\
\hline & Berada pada zona akresi & 0 & 0 & 0 \\
\hline \multicolumn{5}{|c|}{ Pencemaran perairan laut* } \\
\hline \multirow{2}{*}{ Minyak dan Lemak (mg/l) } & $<1$ & 2 & 3 & 6 \\
\hline & $>1$ & 0 & 0 & 0 \\
\hline \multirow{2}{*}{ Kadmium Cd (mg/l) } & $<0,001$ & 2 & 3 & 6 \\
\hline & $>0,001$ & 0 & 0 & 0 \\
\hline \multirow[t]{2}{*}{ Kromium heksavalen $\mathrm{Cr}+6$ (mg/l) } & $<0,005$ & 2 & 3 & 6 \\
\hline & $>0,005$ & 0 & 0 & 0 \\
\hline \multirow[t]{2}{*}{ Timbal Pb) } & $<0,008$ & 2 & 2 & 4 \\
\hline & $>0,008$ & 0 & 0 & 0 \\
\hline \multirow[t]{2}{*}{ Tembaga $\mathrm{Cu}$} & $<0,008$ & 3 & 2 & 4 \\
\hline & $>0,008$ & 0 & 0 & 0 \\
\hline
\end{tabular}


Tabel 3. Kriteria penilaian pemanfaatan ruang yang sesuai

Table 3. Assessment criteria of space utilization of suitable

\begin{tabular}{lll}
\hline Kriteria & Nilai skor & Keterangan \\
\hline Sangat sesuai (S1) & $>80-100$ & $\begin{array}{l}\text { Ruang ini mendukung/berpotensi dan sangat layak sebagai zona } \\
\text { khusus dan tidak menutup kemungkinan untuk dikembangkan. }\end{array}$ \\
Sesuai (S2) & $60-80$ & $\begin{array}{l}\text { Ruang ini mendukung dan layak sebagai zona khusus, namun perlu } \\
\text { diperhatikan syarat-syarat tertentu apabila ingin dikembangkan } \\
\text { sebagai kawasan yang sama. } \\
\text { Ruang ini tidak mendukung dan tidak layak sebagai zona khusus. } \\
\text { Tidak sesuai (N) }\end{array}$ \\
$0-<60$ & $\begin{array}{l}\text { Mungkin dapat dialokasikan untuk zona lindung, khusus dan lain } \\
\text { sebagainya. }\end{array}$ \\
\hline
\end{tabular}

Sumber: Modifikasi Hartoko dan Helmi, 2004.

cara mengidentifikasikan persyaratan lingkungan terhadap parameter zona khusus dengan survei lapangan berdasarkan data dalam Tabel 2, dilakukan berdasarkan skoring dengan pendekatan SIG. Kriteria penilaian dari parameter lingkungan pada zona khusus digunakan sebagai representasi nilai suatu ruang. Kriteria yang digunakan untuk menentukan 3 nilai kelas pada zona khusus yaitu: 1) sangat sesuai (S1);2) sesuai (S2); dan 3) tidak sesuai (N) dengan persamaan (Hartoko \& Helmi, 2004) (Tabel 3).

\section{HASIL DAN PEMBAHASAN}

.Aktivitas pelabuhan pada zona khusus di PLTU Teluk Sirih dan Dempo Pertamina (Persero) berpengaruh besar terhadap kegiatan marikultur di Teluk Kabung Labuhan Cino dan Balai Benih Ikan Pantai (BBIP) Teluk Buo. Hal ini disebabkan karena kekeruhan perairan pada musim hujan yang menyebabkan menurunkan kandungan oksigen terlarut perairan sehingga proses fotosintesis terhambat dan membawa dampak kematian pada biota akuatik khususnya ikan.
Matriks hubungan kompatibilitas pemanfaatan ruang antar kegiatan di pesisir Teluk Bungus (Gambar 2) menunjukkan semua sektor kegiatan membawa potensi konflik terhadap kegiatan lain seperti cemaran limbah dan perubahan fungsi ekologi. Kawasan untuk zona lindung berupa lindung alami, sempadan pantai dan sungai dapat menurun fungsinya dengan keberadaan industri dan pelabuhan pada zona khusus. Antar kegiatan pemanfaatan ruang di pesisir Teluk Bungus dapat merugikan, kecuali pertanian dan pemukiman.

Kegiatan-kegiatan di kawasan pesisir Teluk Bungus yang tidak kompatibel satu dengan yang lain dapat menimbulkan dampak merugikan pada lingkungan sekitarnya. Putra et al., (2015) menambahkan untuk mengatasi dampak tersebut diperlukan pengelolaan lingkungan hidup, baik secara ekologi maupun melalui kebijakan Pemerintah agar kawasan ini dapat dimanfaatkan secara berkelanjutan (sustainable).

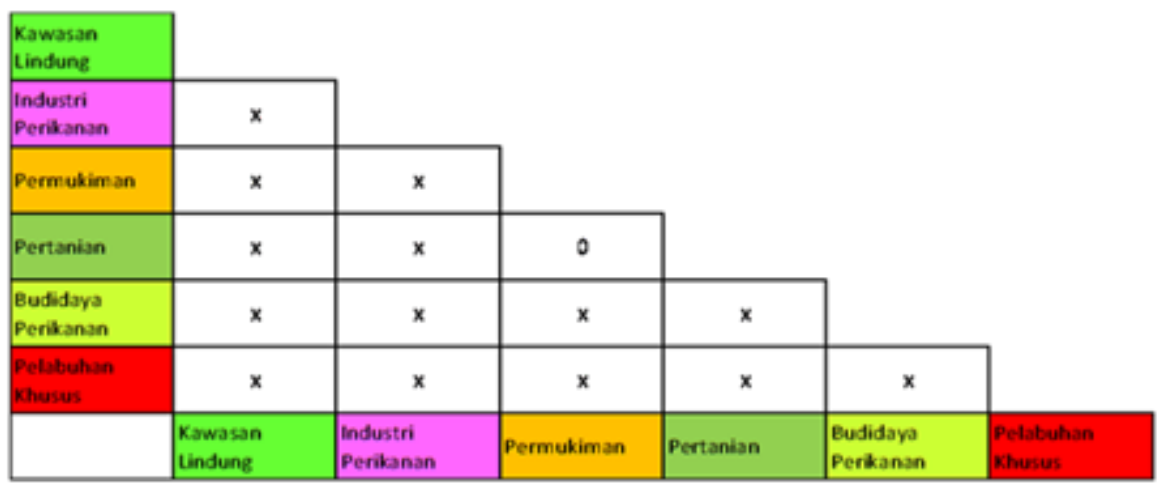

Gambar 2. Matrik hubungan kompatibilitas di kawasan pesisir Teluk Bungus.

Figure 2. Matrix of compatibility relationships in the coastal region of Bungus Bay. Keterangan: $X=$ kegiatan saling merugikan (konflik); $0=$ normal. 


\section{Hasil Parameter Kesesuaian Zona Khusus}

\section{Pasang surut}

Pasang surut merupakan pergerakan permukaan air laut arah vertikal yang disebabkan pengaruh gaya tarik bulan, matahari dan benda angkasa terhadap bumi (Tanto et al., 2017). Grafik pasang surut air laut di perairan Teluk Bungus dibuat berdasarkan nilai surut terendah pada waktu pengukuran dengan jenis pasang surut yang terjadi adalah tipe campuran (Mixed Tide). Hal ini dapat dilihat dari hasil grafik pasang surut perairan Teluk Bungus yang di ukur dari alat Tide/Wave Gauge (Gambar 3). Dari data tinggi muka air tersebut, diperoleh nilai pasang surut (tunggang pasut) sebesar $143 \mathrm{~cm}$. Data yang diambil untuk analisis leastsquare pada 1-31 Agustus 2016.

Dengan nilai komponen pasang surut yang dihasilkan tersebut, maka dapat ditentukan nilai bilang Formzahl, yaitu sebesar 0,4543 (Tabel 4). Sehingga dapat diketahui tipe pasang surut yang terjadi di pesisir Teluk Bungus, yaitu tipe campuran condong semi diurnal $(0,25 \leq \mathrm{F}$ $\leq 1,5$ ). Data pasang surut pada Gambar 3 diperoleh pada pengukuran 1-31 Agustus 2016 dengan nilai tidal range sebesar $143 \mathrm{~cm}$, berdasarkan penelitian Putra et al., (2015) kondisi pasang surut berpengaruh pada dinamika air sekitar pantai. Ini menginformasikan bahwa kesesuaian pasang surut di pesisir Teluk Bungus masuk dalam kategori sangat sesuai.

\section{Tinggi Gelombang Laut}

Gelombang yang terjadi di perairan Teluk Bungus pada Januari-Oktober 2016 memiliki tinggi gelombang yaitu $0,47 \mathrm{~m}-1,6 \mathrm{~m}$. Tinggi gelombang cukup besar terjadi pada Oktober 2016 dengan nilai 0,55-1,6 m, terutama pada 9 hingga 11 Oktober 2016 dengan tinggi gelombang 1,45-1,65 m. Kejadian gelombang yang cukup besar ini tidak dipengaruhi oleh faktor angin di daratan yang tercatat pada situs ECMWF. Tanto et al., (2016) mengasumsikan ini dapat diperkuat dari nilai data angin pada saat terjadinya gelombang besar tersebut, angin di daratan masih adalah rendah (sepoisepoi) sampai sedang. Hal ini dapat terjadi karena tinggi gelombang signifikan yang terukur berada pada laut lepas, sedangkan angin yang terukur masih berada dekat dengan pantai yang hanya bisa membangkitkan gelombang di perairan Teluk Bungus.

\section{Dinamika Pantai}

Abrasi dan akresi merupakan sistem dari dinamika pantai, karena abrasi dan akresi di mulai dari gelombang yang mampu menimbulkan arus (Putra, 2009). Besar kecilnya membawa pengaruh besar terhadap keseimbangan hidrodinamika pantai. Berdasarkan hasil survei lapangan di lokasi zona khusus yaitu: a) PPS Bungus ditemukan akresi di muara sungai antara

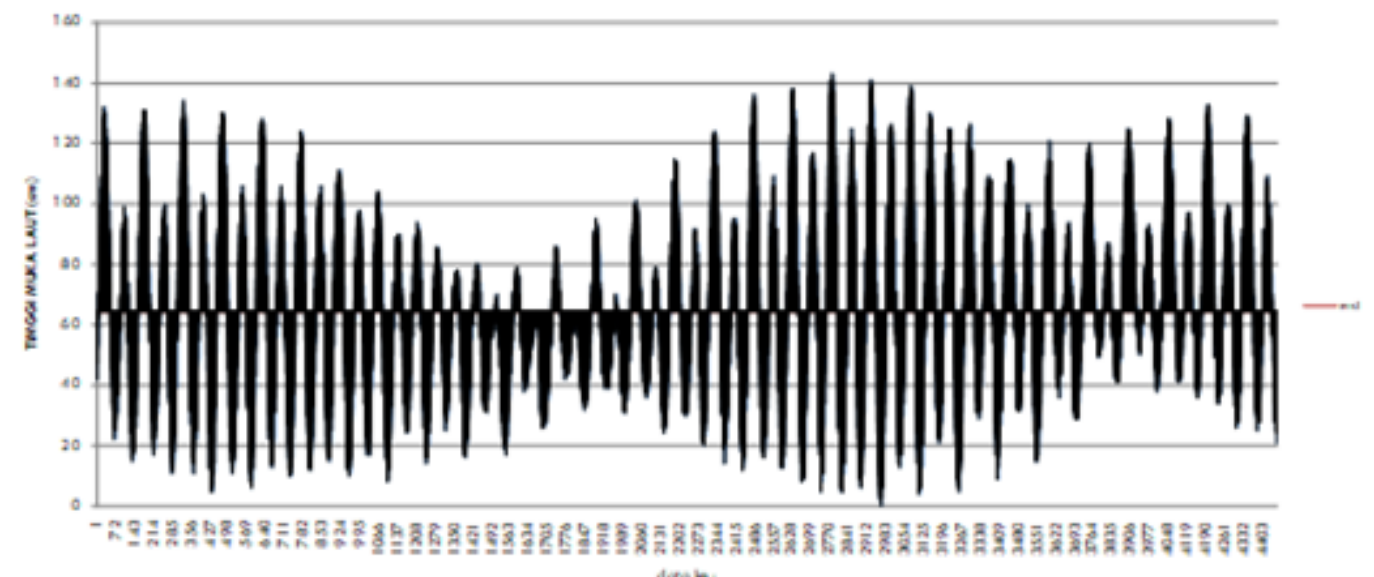

Gambar 3. Grafik Pasang surut di perairan Teluk Bungus.

Figure 3. Tidal graphs in the waters of Bungus Bay.

Tabel 4. Komponen pasang surut di perairan Teluk Bungus

Table 4. Tidal components in the waters of Bungus Bay

\begin{tabular}{|c|c|c|c|c|c|c|c|c|c|c|}
\hline & S0 & M2 & S2 & N2 & K1 & 01 & M4 & MS4 & $\mathrm{K} 2$ & P1 \\
\hline A & 64,51 & 38,43 & 8,24 & 8,29 & 8,51 & 15,34 & 5,86 & 4,53 & 2,03 & 0,9 \\
\hline $\mathrm{g}^{\circ}$ & & 22,81 & 247,19 & 15,88 & 152,14 & 226,01 & 193,07 & 156,75 & 113,97 & 24,59 \\
\hline
\end{tabular}

JURNAL KELAUTAN NASIONAL, Vol. 15, No 2, Agustus 2020, Hal. 91-102 
PPS Bungus dengan Pelabuhan ASDP; b) pelabuhan Pertamina (Persero) ditemukan adanya abrasi di muara sungai Cindakir sampai ke dermaga pelabuhan Pertamina (Persero); dan c) PLTU Teluk Sirih ditemukan adanya abrasi dan akresi.

Mekanisme abrasi dan akresi disebabkan sudut datang gelombang kecil atau gelombang yang datang kurang dari $1 \mathrm{~m}$ di lokasi pelabuhan, maka terbentuk rip current dengan arah menjauhi pantai di samping terbentuknya arus menyusur pantai. Menurut Cui et al., (2015) mekanisme pembentukan abrasi dan akresi ditentukan oleh besarnya sudut datang gelombang yang menyusur pantai (longshore current) yang berpengaruh terhadap transport sedimen. Sedimen yang terangkut akan menimbulkan abrasi dan akresi di lokasi lain.

\section{Pencemaran Perairan Laut Minyak dan Lemak}

Berdasarkan hasil analisis laboratorium ditemukan nilai parameter cemaran perairan minyak \& lemak di perairan PLTU Teluk Sirih, Perairan Pelabuhan Pertamina (Persero) dan PPS Bungus berada pada kategori sangat sesuai yaitu $0,41-0,59 \mathrm{mg} / 1$. Kandungan minyak dan lemak yang dipersyaratkan pada baku mutu air laut dalam KEPMEN LH No. 51 Tahun 2004 adalah 5 mg/l. Ghufran \& Kordi, (2003); Putra et al., (2017) menjelaskan minyak dan lemak lebih dari $5 \mathrm{mg} / \mathrm{l}$ untuk biota laut dan marikultur mengakibatkan oksigen dari udara dapat terhalang masuk ke laut karena lapisan minyak, sehingga nilai kandungan oksigen terlarut menjadi menurun dan dapat mematikan organisme yang memerlukan oksigen cukup banyak untuk aktivitas hidupnya.

\section{Kadmium $C d$}

Kadmium (Cd), masuk keperairan akibat dari aktivitas manusia. Pada perairan Teluk Bungus Cd berasal dari kegiatan domestik. Logam berat $\mathrm{Cd}$ dapat berasal dari pestisida, insektisida, limbah domestik, pencemaran batubara dan industri (pelabuhan). $\mathrm{Cd}$ di perairan PLTU Teluk Sirih, Perairan Pelabuhan Pertamina (Persero) dan PPS Bungus berada pada kategori tidak sesuai yaitu 0,0013-0,0031 mg/l. Kandungan Cd yang dipersyaratkan pada baku mutu ait laut dalam KEPMEN LH No. 51 Tahun 2004 untuk biota laut dan marikultur adalah $0,001 \mathrm{mg} / 1$. Suatu kecenderungan para nelayan melakukan pengecatan perahu atau kapal dengan menggunakan cat yang mengandung unsur $\mathrm{Cd}$ turut mempengaruhi konsentrasi $\mathrm{Cd}$ perairan, seperti docking kapal di PPS Bungus. Cd mempunyai penyebaran yang sangat luas di perairan laut. Hanya ada satu jenis mineral Cd yaitu greennockite $(\mathrm{CdS})$ yang selalu ditemukan bersamaan dengan mineral spalerite (ZnS). Singh et al., (2015) menjelaskan bahwa mineral CdS sangat jarang ditemukan di perairan laut, sehingga dalam ekspolitasi logam $\mathrm{Cd}$, biasanya merupakan hasil sampingan dari peristiwa peleburan dan refining bijih seng $(\mathrm{Zn})$.

\section{Kromium heksavalen $\mathrm{Cr}+6$}

Kromium heksavalen $(\mathrm{Cr}+6)$ di perairan PLTU Teluk Sirih, Perairan Pelabuhan Pertamina (Persero) dan PPS Bungus berada pada kategori tidak sesuai yaitu 0,008 $0,013 \mathrm{mg} / \mathrm{l}$. Kandungan $\mathrm{Cr}+6$ yang dipersyaratkan pada baku mutu ait laut dalam KEPMEN LH No. 51 Tahun 2004 untuk biota laut dan marikultur adalah $0,005 \mathrm{mg} / \mathrm{l}$. Cr+6 yang tinggi disebabkan karena pada pengambilan sampel kondisi air laut sedang pasang naik dan gelombang juga besar. $\mathrm{Cr}+6$ tertinggi ditemukan di perairan PLTU Teluk Sirih menuju laut lepas) dengan nilai $0,013 \mathrm{mg} / 1$. Ternyata konsentrasi $\mathrm{Cr}+6$ memang sudah cukup tinggi di lautan lepas, sehingga karena faktor gelombang yang cukup besar $\mathrm{Cr}+6$ akan ikut terbawa dan akan menyebabkan daerah di sekitar perairan Teluk Bungus akan terkontaminasi. Faktor yang menyebabkan konsentrasi $\mathrm{Cr}+6$ cukup tinggi adalah karena aktivitas di perairan laut (Scheiderich et al, 2015). Kondisi tersebut dapat dilihat pada 3 lokasi pelabuhan khusus di kawasan pesisir Teluk Bungus, dimana pada lokasi tersebut terdapatnya kapal-kapal yang berlabuh yang membuang air balasnya ke laut dan juga karena lokasinya tidak begitu jauh dari pantai sehingga sering terjadi pengadukan air dengan sedimen yang banyak mengandung $\mathrm{Cr}+6$.

\section{Timbal Pb}

Timbal $(\mathrm{Pb})$ di perairan PLTU Teluk Sirih berada pada kategori tidak sesuai antara 0,009-0,017 mg/l. Kandungan $\mathrm{Pb}$ yang dipersyaratkan pada baku mutu ait laut dalam KEPMEN LH No. 51 Tahun 2004 untuk biota laut dan marikultur adalah $0,008 \mathrm{mg} / \mathrm{l} . \mathrm{Pb}$ tertinggi ditemukan pada lokasi 24 (PLTU Teluk Sirih menuju laut lepas) dengan nilai $0,017 \mathrm{mg} / \mathrm{l}$.

\section{Tembaga $\mathrm{Cu}$}

Tembaga $(\mathrm{Cu})$ di perairan PLTU Teluk Sirih, Perairan Pelabuhan Pertamina (Persero) dan PPS Bungus berada pada kategori sangat sesuai antara 0,010-0,014 $\mathrm{mg} / \mathrm{l}$. Kandungan $\mathrm{Cu}$ yang dipersyaratkan pada baku mutu air laut dalam KEPMEN LH No. 51 Tahun 2004 untuk biota laut dan marikultur adalah $0,008 \mathrm{mg} / 1 . \mathrm{Cu}$ tertinggi ditemukan pada lokasi 1 (PPS Bungus) dengan nilai $0,014 \mathrm{mg} / \mathrm{l}$. Konsentrasi Cu biasanya terjadi secara langsung dari atmosfir dan karena tumpahan minyak dari kapal-kapal pelabuhan serta mineral yang banyak 
Tabel 5. Hasil kesesuaian parameter zona khusus

Table 5. A result of parameter suitability of special zones

\begin{tabular}{|c|c|c|c|c|}
\hline \multirow{2}{*}{$\begin{array}{l}\text { Lokasi } \\
\text { PPS Bungus }\end{array}$} & \multicolumn{2}{|l|}{ Parameter } & \multirow{3}{*}{$\begin{array}{l}\text { Kategori } \\
\text { sesuai } \\
\text { sangat sesuai }\end{array}$} & \multirow{2}{*}{$\frac{\text { Skor }}{5}$} \\
\hline & tinggi gelombang (m) & $1,5-1,7$ & & \\
\hline & pasang surut (cm) & 143 & & 4 \\
\hline & dinamika pantai: & & & \\
\hline & abrasi & tidak ada & sangat sesuai & 8 \\
\hline & akresi & Ada & tidak sesuai & 0 \\
\hline & cemaran perairan: & & & \\
\hline & minyak dan lemak & 0,59 & sangat sesuai & 6 \\
\hline & kadmium (Cd) & 0,0031 & tidak sesuai & 0 \\
\hline & kromium heksavalen $\left(\mathrm{Cr}^{+6}\right)$ & 0,011 & tidak sesuai & 0 \\
\hline & timbal $(\mathrm{Pb})$ & 0,009 & tidak sesuai & 0 \\
\hline & tembaga $(\mathrm{Cu})$ & 0,014 & sangat sesuai & 4 \\
\hline \multirow{11}{*}{$\begin{array}{l}\text { Pelabuhan } \\
\text { Pertamina } \\
\text { (Persero) }\end{array}$} & tinggi gelombang (m) & $1,5-1,7$ & sesuai & 5 \\
\hline & pasang surut $(\mathrm{cm})$ & 143 & sangat sesuai & 4 \\
\hline & dinamika pantai: & & & \\
\hline & abrasi & Ada & tidak sesuai & 0 \\
\hline & akresi & tidak ada & sangat sesuai & 8 \\
\hline & cemaran perairan & & & \\
\hline & minyak dan lemak & 0,59 & sangat sesuai & 6 \\
\hline & kadmium (Cd) & 0,0031 & tidak sesuai & 0 \\
\hline & kromium heksavalen $\left(\mathrm{Cr}^{+6}\right)$ & 0,011 & tidak sesuai & 0 \\
\hline & timbal $(\mathrm{Pb})$ & 0,009 & tidak sesuai & 0 \\
\hline & tembaga $(\mathrm{Cu})$ & 0,014 & sangat sesuai & 4 \\
\hline \multirow{11}{*}{$\begin{array}{l}\text { PLTU Teluk } \\
\text { Sirih }\end{array}$} & tinggi gelombang (m) & $1,5-1,7$ & sesuai & 5 \\
\hline & pasang surut $(\mathrm{cm})$ & 143 & sangat sesuai & 4 \\
\hline & dinamika pantai: & & & \\
\hline & abrasi & Ada & tidak sesuai & 0 \\
\hline & akresi & Ada & tidak sesuai & 0 \\
\hline & cemaran perairan: & & & \\
\hline & minyak dan lemak & 0,59 & sangat sesuai & 6 \\
\hline & kadmium (Cd) & 0,0031 & tidak sesuai & 0 \\
\hline & kromium heksavalen $\left(\mathrm{Cr}^{+6}\right)$ & 0,011 & tidak sesuai & 0 \\
\hline & timbal $(\mathrm{Pb})$ & 0,009 & tidak sesuai & 0 \\
\hline & tembaga $(\mathrm{Cu})$ & 0,014 & sangat sesuai & 4 \\
\hline
\end{tabular}

terkandung dalam laut (Arifin et al., 2012).

Hasil skoring berdasarkan parameter kesesuaian pada zona khusus (Gambar 4 dan Tabel 5) pada kawasan pesisir Teluk Bungus, yaitu: 1) PPS Bungus dengan luas 26,15 ha menunjukkan kategori sangat sesuai dengan skor 90; 2) Pelabuhan Pertamina (Persero) dengan luas 19,2 ha menunjukkan kategori sangat sesuai dengan skor 90; dan 3) PLTU Teluk Sirih dengan luas 46,32 ha menunjukkan kategori sesuai dengan skor 63 (Tabel 6), nilai tersebut berada pada skor $60-80$ yang menunjukkan ruang ini mendukung /layak sebagai zona pemanfaatan khusus, namun perlu diperhatikan syarat-syarat tertentu apabila ingin dikembangkan sebagai zona yang sama.

Daerah yang merupakan pusat kegiatan industri dan perekonomian yang berada pada zona khusus dengan radius 3,5 dan $7 \mathrm{~km}$ dari pusat Kecamatan menginformasikan zona tersebut berada dalam kategori sangat sesuai dan sesuai, ini disebabkan lokasi ruang yang dimanfaatkan berada pada sempadan pantai dan sungai serta memiliki vegetasi sebagai zona penyangga (buffer zone) yang baik (Gambar 3).

Alokasi dan sebaran zona penyangga sangat diperlukan terutama pada daerah yang aktivitasnya berpotensi membawa dampak pada daerah lain, sehingga nilai zona 


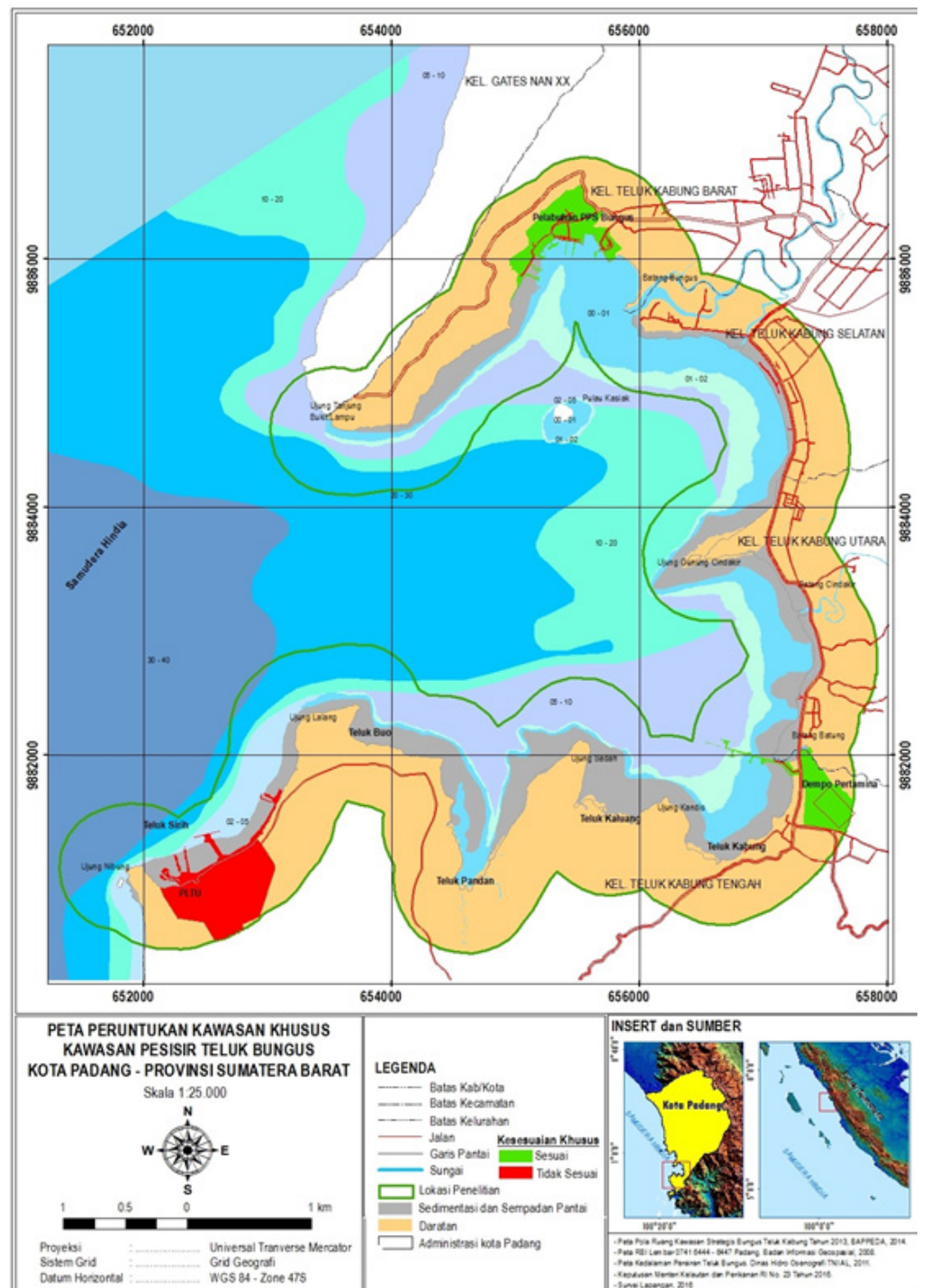

Gambar 4. Peta kesesuaian zona khusus pada kawasan pesisir Teluk Bungus. Figure 4. Map of special zone suitability on the coastal region of Bungus Bay.

lain menjadi menurun bahkan tidak dapat difungsikan lagi. Zona penyangga pada kawasan pesisir Teluk Bungus alokasi penetapan ruangnya didistribusikan pada kegiatan pelabuhan khusus yang berpotensi mencemari daerah lainnya. Menurut Dahuri et al., (2001) lebar minimum zona penyangga sebesar 7,6 $\mathrm{m}$ ditambah $0,6 \mathrm{~m}$ untuk setiap $1 \%$ kemiringan lereng antara muka air dengan hutan. Selain berperan secara ekologi fungsi zona penyangga sebagai pelindung untuk melindungi kualitas massa air serta menahan bahan pencemar dan memperlambat run off sehingga sedimentasi dapat dikurangi.

\section{KESIMPULAN DAN SARAN}

Analisis kesesuaian berdasarkan parameter lingkungan

Tabel 6. Skor parameter kesesuaian zona khusus

Table 6. A score of parameter suitability of special zones

\begin{tabular}{lllll}
\hline Lokasi & Skor & Luas & Kategori \\
\hline Pelabuhan PPS & 27 & 90 & 26,15 & sangat sesuai \\
Pelabuhan Pertamina (Persero) & 27 & 90 & 19,2 & sangat sesuai \\
PLTU Teluk Sirih & 19 & 63 & 46,32 & sesuai \\
\hline
\end{tabular}

Kesesuaian Pemanfaatan Ruang Pada Zona Khusus (Pelabuhan) di Kawasan Pesisir Teluk Bungus Kota Padang - Aprizon Putra, Ahmad Iqbal Baqi, Fuji Astuti Febria, Wilson Novarino, Dedi Hermon, Indang Dewata, Try Al Tanto, 
zona khusus (pelabuhan) pada kawasan pesisir Teluk Bungus menunjukkan kategori sangat sesuai dan sesuai yaitu: 1) PPS Bungus dengan luas 26,15 ha menunjukkan kategori sangat sesuai dengan skor $90 ; 2)$ Pelabuhan Pertamina (Persero) dengan luas 19,2 ha menunjukkan kategori sangat sesuai dengan skor 90; dan 3) PLTU Teluk Sirih dengan luas 46,32 ha menunjukkan kategori sesuai dengan skor 63, ini menunjukkan keberadaan PLTU Teluk Sirih tidak menurunkan kondisi lingkungan pada daerah tersebut. Kondisi tiap lokasi pada zona khusus sebagai zona pemanfaatan berada pada batas maksimal. Hal ini disebabkan karena lokasi ruang yang dimanfaatkan berada pada sempadan pantai dan sungai yang memiliki vegetasi sebagai zona penyangga (buffer zone) yang baik.

\section{UCAPAN TERIMA KASIH}

Terimakasih kepada rekan-rekan peneliti, teknisi, dan administrasi Loka Riset Sumber Daya dan Kerentanan Pesisir BRSDM KP serta tak lupa kepada koordinator program Magister Ilmu Lingkungan Universitas Andalas atas dukungan morilnya.

\section{DAFTAR PUSTAKA}

Arifin, B., Deswita., \& Loekman, U. (2012). Analisis Kandungan Logam $\mathrm{Cd}, \mathrm{Cu}, \mathrm{Cr}$ dan $\mathrm{Pb}$ dalam Air Laut di Sekitar Perairan Bungus Teluk Kabung Kota Padang. Jurnal Dampak, 9(2), 139-145.

Badan Koordinasi Survei dan Pemetaan Nasional (Bakosurtanal). (2007). Prediksi Pasang Surut 2008. Cibinong: Bidang Medan Gaya berat dan Pasang Surut - Bakosurtanal.

Badan Perencanaan PembangunanDaerah(BAPPEDA). (2012). Rencana Tata Ruang Wilayah (RTRW) Kota Padang 2010-2017. Padang: Pemerintahan Kota Padang.

Cui, L., Ge, Z., Yuan, L., \& Zhang, L. (2015). Vulnerability Assessment of the Coastal Wetlands in the Yangtze Estuary, China to SeaLevel Rise. Journal Estuarine, Coastal and Shelf Science. 156, 42-51.

Dahuri, R., Jacub, R., Ginting, S.P., \& Sitepu, M. (2001). Pengelolaan Sumberdaya Wilayah Pesisir dan Lautan secara Terpadu. Jakarta: PT Pradnya Paramita.
Fadhilah, L. T., Kamal, E., Mustapha, M. A., \& Putra, A. (2019). Land Cover Change Mangrove Ecosystem in the Coastal Area of Bungus Teluk Kabung Padang City. Sumatra Journal of Disaster, Geography and Geography Education, 3(2), 165-169.

Ghufran, M., \& Kordi, K. (2003). Budidaya Ikan Laut di Keramba Jaring Apung. Jakarta: Bineka Cipta.

Hartoko, A., \& Helmi, M. (2004). Development of Digital Multilayer Ecological Model for Padang Coastal Water (West Sumatra). Journal Coastal Development, 7(3), 129-136.

Hermon, D., Putra, A., \& Oktorie, O. (2018). Suitability Evaluation of Space Utilization Based on Enviromental Sustainability at The Coastal Area of Bungus Bay in Padang City. International Journal of GEOMATE, 14(41), 193-202.

Husrin, S., Putra, A., Kusumah, G., Gemilang, W.A., Ramdhan, M., \& Gunawan, D. (2015). Analisis Rute Evakuasi Tsunami Di Pelabuhan Perikanan Teluk Bungus. Prosiding Simposium Mitigasi Bencana Tsunami, 1-13.

Keputusan Menteri Kelautan dan Perikanan (KEPMEN KP) No. 82 Tahun 2015 tentang Wilayah kerja dan wilayah pengoperasian Pelabuhan perikanan Samudera Bungus. Jakarta: Direktur Jenderal Peraturan Perundang-Undangan Kementerian Hukum dan Hak Asasi Manusia Republik Indonesia.

Keputusan Menteri Negara Lingkungan Hidup (KMNLH) No 51. Tahun. 2004. Baku Mutu Air Laut. Jakarta: Kementerian Lingkungan Hidup.

Li. Y., Zhang, X., Zhao, X., Ma, S., Cao, H., \& Cao, J. (2016). Assessing Spatial Vulnerability from Rapid Urbanization to Inform Coastal Urban Regional Planning. Journal Ocean \& Coastal Management, 123, 53-65.

Peraturan Daerah (PERDA) No. 4 Tahun 2012 tentang Rencana Tata Ruang Wilayah Kota Padang Tahun 2010-2030. Padang: Pemerintahan Kota Padang.

Peraturan Menteri Lingkungan Hidup (PERMEN LH) No. 5 Tahun 2014 tentang Baku Mutu Air Limbah. Jakarta: Kementerian Lingkungan 
Hidup.

Peraturan Menteri Kelautan dan Perikanan (PERMEN KP) No. 23 Tahun 2016 tentang Perencanaan Pengelolaan Wilayah Pesisir dan Pulau-Pulau Kecil. Jakarta: Direktur Jenderal Peraturan Perundang-Undangan Kementerian Hukum dan Hak Asasi Manusia Republik Indonesia.

Purbani, D., Damai, A., Yulius., Mustikasari, E., Salim. H., \& Heriati, A. (2016). Pengembangan Industri Perikanan Tangkap di Perairan Barat Sumatera Berbasis Ekonomi Biru. Jurnal Manusia dan Lingkungan, 23(2), 233-240.

Putra, A., Husrin, S., \& Mutmainah, H. (2017). Pola Sebaran Kualitas Air Berdasarkan Kesesuaian Baku Mutu Untuk Biota Laut di Teluk Kendari Provinsi Sulawesi Tenggara. Maspari Journal, 9(1), 51-60.

Putra. A., Tanto, T.A., \& Ilham. (2016). Aplikasi Citra Satelit Untuk Identifikasi Perubahan Luasan Mangrove di Teluk Bungus Kota Padang. Prosiding Seminar Nasional Sains dan Atmosfer. 33-38.

Putra. A., Tanto, T.A., \& Ilham. (2015). Granules Size Analysis and Sedimentation Rate to Coral Reefs and Seagrass in the Bungus Bay Waters Padang City. Proceeding 2015 International Conference on "Green Development in Tropical Regions". 89-97.

Putra, A., Husrin, S., Tanto, T.A., \& Pratama, R. (2015). Kerentanan Pesisir Terhadap Perubahan Iklim Di Timur Laut Provinsi Bali. Majalah Ilmiah Globe. 17(1), 43-50.

Putra, A. (2009). Aksi Penanaman/Penghijauan Tepi Pantai Dalam Mengurangi Dampak Pemanasan Global dan Abrasi dipantai Air Tawar Barat, Kecamatan Padang Utara, Kota Padang (21 November 2009). Laporan Kegiatan Pengabdian Masyarakat. Studi Lingkungan Hidup Jurusan Geografi, Padang: Universitas Negeri Padang.

Scheiderich. K., Amini, M., Holmden, C., \& Francois, R. (2015). Global variability of chromium isotopes in seawater demonstrated by Pacific, Atlantic, and Arctic Ocean samples. Procedia of Earth and Planetary Science Letters. Vol. 423, 87-97.
Singh, C. R., Kathiresan, K., \& Anandhan, S. (2015). A review on marine based nanoparticles and their potential applications. African Journal of Biotechnology. 14(18), 1526- 1532.

Tanto, T.A., Putra, A., \& Ilham. (2014). Monitoring Ekosistem Pesisir Kawasan Teluk BungusPadang, Sumatera Barat. Prosising Seminar Nasional Kelautan 2014, 27-41.

Tanto, T. A., Husrin, S., Wisha, U. J., Putra, A., Putri, R. K., \& Ilham. (2016). Karakteristik Oseanografi Fisik (Batimetri, Pasang Surut, Gelombang Signifikan dan Arus Laut) Perairan Teluk Bungus. Jurnal Kelautan. 9(2), 107-121.

Tanto, T. A., Wisha, U. J., Kusumah, G., Pranowo, W. S., Husrin, S.., Ilham., \& Putra, A. (2017). Karakteristik Arus Laut Perairan Teluk Benoa -Bali. Jurnal Ilmiah Geomatika. 23(1), 37-48.

Undang-Undang (UU) No. 27 Tahun 2007 tentang Pengelolaan Wilayah Pesisir dan Pulau-Pulau Kecil. Lembaran Negara Republik Indonesia Nomor 4739.

Yulius., Tanto, T. A., Ramdhan, M., Putra, A., \& Salim, H. L. (2014). Perubahan Tutupan Lahan di Pesisir Bungus Teluk Kabung, Sumatra Barat Tahun 2003-2013 menggunakan Sistem Informasi Geografis. Jurnal Ilmu dan Teknologi Kelautan Tropis. 6(2), 311-318. 
